\title{
School Libraries in Portugal (1996-2016): looking into the future
}

\author{
Elsa Conde \\ School Libraries Network Agency \\ Av. 24 de Julho, 140 1399-025 Lisboa \\ Portugal \\ elsa.conde@mail-rbe.org
}

\begin{abstract}
At the end of 2016 the Portuguese School Libraries Network Program completes 20 years of existence.

The aim of this paper is to show the results achieved by the SLNP over these 20 years and its current work to address the challenges of the future.

The requirement of the existence of school library ensuring its educational, formative and cultural function, as well as its leadership, quality and training principles marked the first ten years of the Program.

In recent years, a second stage due to the digital revolution becomes central prove to the destination of school libraries, leading to face them as "a window to the real and online world".

The Program will pursue its goals and contribute to the new phase of development of libraries through the continuation of a strong focus of all actors in this public policy.
\end{abstract}

No final de 2016 o Programa Rede de Bibliotecas Escolares completa 20 anos de existência.

Constitui objeto desta comunicação dar a conhecer os resultados alcançados pelo PRBE ao longo destes 20 anos e o seu trabalho atual para responder aos desafios do futuro.

Os primeiros dez anos do Programa firmaram a exigência da biblioteca na escola e o reconhecimento da sua função pedagógica, formativa e cultural, de acordo com princípios de liderança, qualidade e formação.

Nos últimos anos, uma segunda etapa decorrente da revolução digital tem vindo a revelar-se central para o destino das bibliotecas escolares, levando a encarálas como "uma janela para o mundo físico e digital".

O Programa pretende prosseguir a sua missão e contribuir para a nova fase de desenvolvimento das bibliotecas, através da continuação de uma forte aposta de todos os atores nesta política pública. 
Keywords: School Libraries; School Libraries Network Program; Sustainability; Innovation.

\section{Introduction}

The development of a network of school libraries in Portugal has a real and symbolic value. In a country marked until the end of the twentieth century by very deficient education levels and serious illiteracy problems, the emergence of a public policy for the promotion of reading levels and the success it provides through school action and their libraries is an important milestone that the future will certainly register.

With such adverse historical past, in which reading habits and skills didn't make their path, and the reading bases were only feebly sedimented, it becomes even more difficult to deal with the problem of literacy because of its current complexity and consequent demand for even higher decoding, analysis and critical capabilities. Knowing how to read implies currently to be able to read well, on all platforms and formats, and libraries are the physical and virtual place where this competence can best be trained and freely exercised.

The School Libraries Network Program (SLNP) embarked on this mission to install a network of school libraries able to support the building of a democratic school where access to reading, information and knowledge would boost the development of the country and the creation of a more free and enlightened society. It was believed then, as it is now, that education is a pillar of development and citizenship and that it is not possible to conceive good schools without good library services.

To accomplish this goal, the Ministries of Education and Culture created in 1995 a working group to analyze and propose measures in order to encourage the use of the book in teaching methods and school time organization and the development of libraries in schools. Taking into consideration the proposals, both ministries started in 1996 the phased release of a program for the installation of a network of school libraries, based on the principles and guidelines contained in the produced report Launching the School Libraries Network. They are as following:

- School libraries are understood as basic resources of the Educational System and should be recognized as playing a central role in reading and literacy, acquisition of information skills and deepening of culture in general;

- Each library should be seen as a free access multimedia resource center, for research and production in different media;

- To achieve their goals, libraries must meet a set of conditions: space and equipment adapted to the diversity of their functions, diversified collections adjusted to the interests and 
needs of the school community, a team of teachers and technicians with adequate training and a budget of their own;

-School libraries are conceived as fundamental cores of the pedagogical organization of schools and essential instruments for the curriculum development, linked to the development of teaching and school activities and to the occupation of free time and leisure;

-The development of a school library should be experienced as an endogenous process, although stimulated and supported from the outside, and as an organizational innovation capable of inducing changes in the school itself, and to that extent, inseparable from its pedagogic project.

To manage the Program it was created an agency directly dependent on the governing team of the Ministry of Education (ME), responsible for ensuring the planning and coordination of the installation process and the development of school libraries, according to the stated assumptions.

After 20 years, the SLNP has more than 2,400 libraries in schools of all levels of education and distributed throughout the country (Fig. 1).

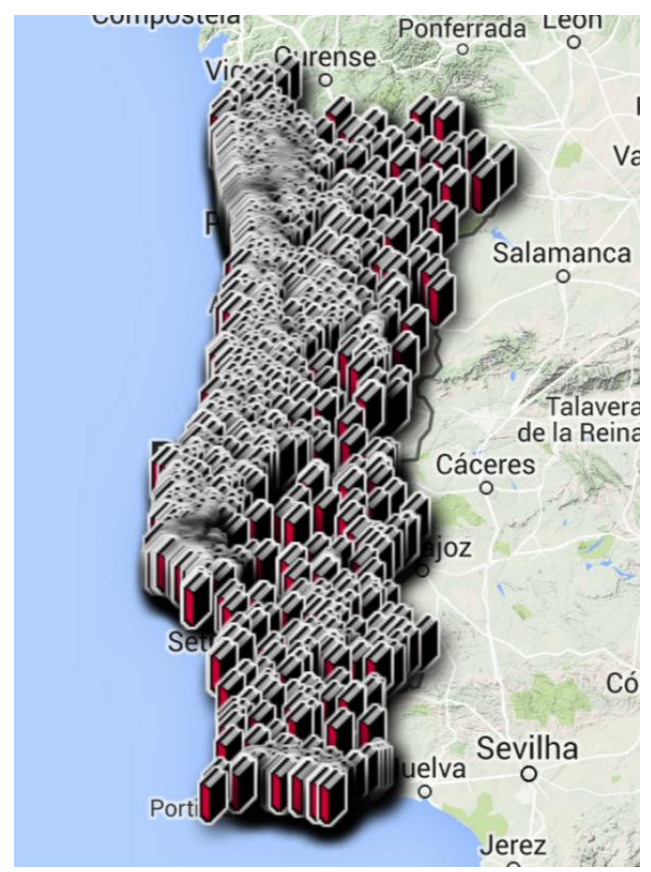

Fig. 1. School libraries distribution in Portugal

These libraries are natural places within the school for the enjoyment and educational and cultural development of young people:

- They promote the contact with the book and other cultural goods and reading habits, stimulating the curiosity, imagination and love for literature, the arts and science; - They develop students' reading and literacies skills (visual, information, media, ...); 
- They promote innovation through the exploration of environments, resources and tools for processing, production and sharing information on different supports and formats;

- They stimulate creativity, critical thinking and autonomy through active methodologies for participation, collaboration and interaction with situations and rich and diverse learning experiences;

- They inspire transversal activities, projects and partnerships with the school and other institutions, local and national, in the fields of language, science, the arts and other crosscurricular knowledge.

\section{New challenges}

Although the philosophy and ideas referred to date back to the creation of the Program, being adapted over time according to new realities, it is quite clear how this concept of school library and its representation have changed in relation with the development and change of the social, educational and technological contexts.

Libraries are currently crossing a critical phase of its evolution. The expansion of digital and Internet made the access to the world of information and communication global, instantaneous and independent of any mediation, reconfiguring libraries as educational and cultural structures of socialization and learning for the critical and responsible use of information, its transformation into knowledge and the personal and social growth of individuals.

In the digital society we are in, it's not enough for young people to have easy access to technologies and information. The young are required to increasingly dominate a wide range of skills:

- Basic skills of reading, writing and speaking, with increasingly frequent use of different languages (textual, audio, video,...);

- Digital skills for using and handling technological tools to access, process, produce and communicate information;

- Media and information skills that allow dealing with information and communication in different social environments, in a participatory, critical and socially responsible way.

More than mere places of location, access and consumption of information, school libraries are regarded today as creative spaces of knowledge construction and communication where reading, digital, media and information skills are learned and exercised.

Aware of these challenges and requirements, the SLNP was equipped with a set of instruments to help him manage the change and face the new challenges: A strategic 
development framework, an evaluation model for school libraries and a learning referential for the pedagogical work with the students.

The SLNP Strategic Framework: 2014-20 defines a set of quality standards for which libraries should progressively tend to, guiding the Program and the school libraries vision, in articulation with the overall objectives set by the Europe 2020 strategy for the area of Education. This Strategic Framework is implemented through an action plan that includes the goals and measures according to the defined broad lines.

The School Libraries Evaluation Model: 2014-17 aims to promote the continuous improvement of the libraries performance, helping libraries to identify the scenarios that best match their situation and realize what is at stake in order to achieve a higher level of performance. This model has been applied in over 1,300 libraries throughout the period 2010-13, after which it was reformulated to adapt to the changes and challenges of the present and guide the new cycle of development and evaluation of libraries.

The benchmark Learning with the School Library established in 2012 contains a set of learning standards and examples of strategies and activities associated with reading, media and information literacies, in order to facilitate their integration into curriculum activities developed by libraries with students and teachers. Launched initially as a pilot project, it is now being disseminated in all schools. More than 500 schools are doing its implementation.

Today we can say that the mission of the SLNP is to try that:

school libraries while aggregators of diverse resources and expertise become a place implied in pedagogical practices change, supporting learning, the curriculum, the development of digital, media and information literacy, the growth of critical readers and citizenship building.

To meet these mission requirements the Program established in 2016 the pursuing on the following objectives:

- To apply the necessary procedures for the integration and installation of libraries and support their development at various levels: space, equipment, furniture, collections and human resources;

- To empower school libraries to continually adjust to the demands posed by technological evolution;

- To support the creation of union catalogs for schools, in collaboration with public libraries;

- To produce technical tools to support school libraries actions; 
- To support school libraries in order to improve reading levels and reading habits, contributing to the implementation of the curriculum;

- To support the action of school libraries as centers for the promotion of reading, media and information literacy, in order to improve learning and academic achievement;

- To produce contents to support the curriculum;

- To promote the acquisition, use and production of digital resources in order to improve learning adapted to current needs;

- To support projects of excellence that will improve the quality of teaching and the performance of the educational system itself;

- To create training plans for literacies through partnerships with training institutions and other entities;

- To promote the quality of school libraries services through evaluation procedures.

Let us take a look at the key dimensions of these goals considering the existing background, the imperative changes and some illustrative examples, keep reminding that the main objective is the consistent and sustainable development of the SLNP.

\section{Integration and installation of school libraries}

The adoption of an integrated policy for libraries, based on applications and implementation of financial resources made available by the program in the creation and renovation of facilities, purchase of specific furniture, modernization of equipments, communication networks, acquisition of rich and diverse collections, widespread use of standard librarymanagement systems and allocation of qualified human resources, proved to be essential for the optimization of investments.

Currently there are three types of applications: Integration, Rehabilitation and Merit. Integration Application intends the inclusion in the Network of public K12 schools.

At this time, 2426 schools are part of the Network (Fig. 2), representing a direct investment of around EUR 50 million. 1 million students are benefiting from a library in their schools, or if the number of students is reduced as it happens in some elementary schools, they benefit from a library service provided by the respective cluster headquarter. As all schools of the 2nd and 3rd cycles and Secondary Education are already integrated, the application intends at this stage mainly to incorporate the elementary schools with more students that are not yet included in the Network. 


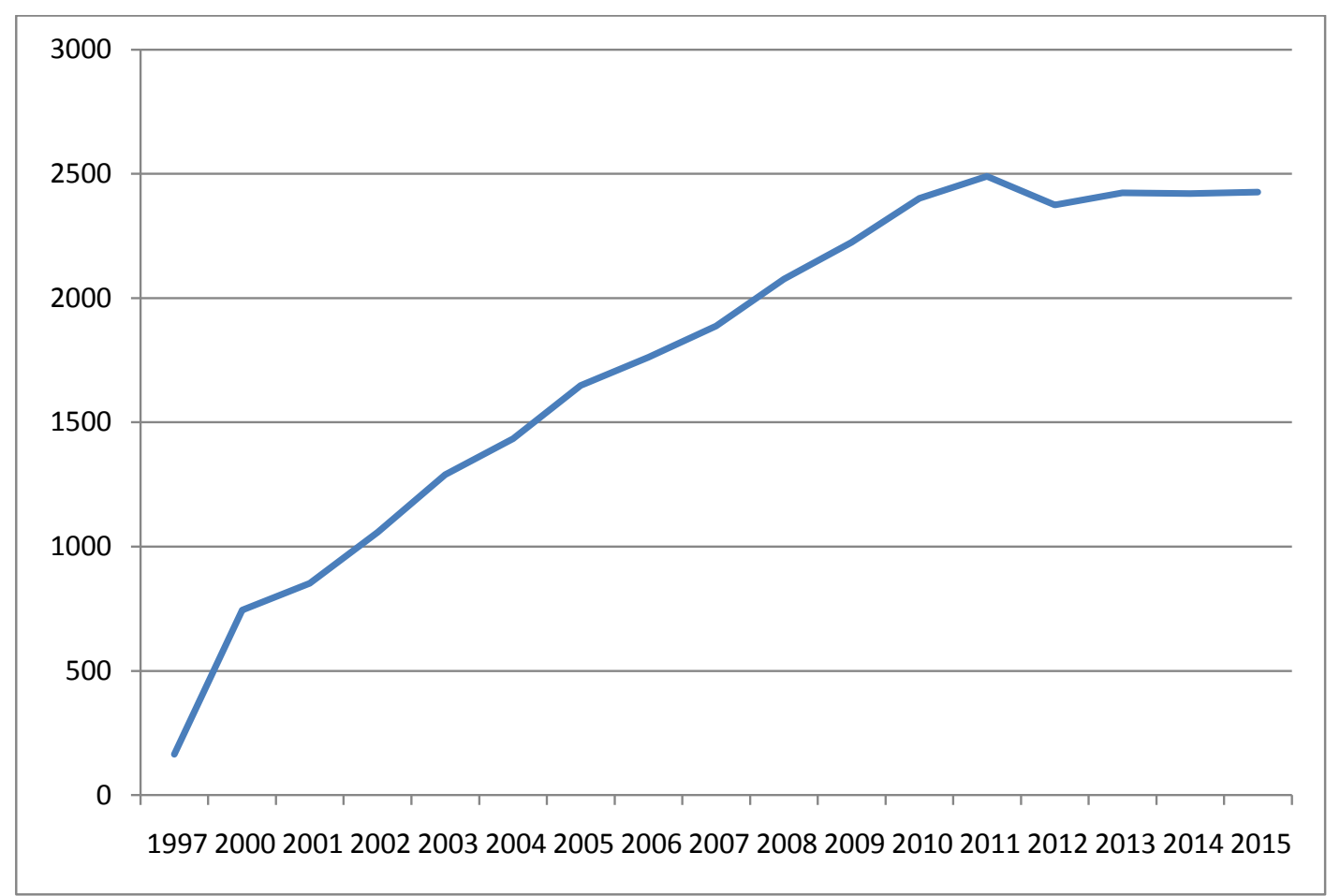

Fig. 2. School Libraries in the SLNP per year: 1997-2015

The Rehabilitation Application intends to support the restructuring of libraries that joined the network some years ago or whose schools have been modified and justify a new intervention.

Launched since 2005 the Application Ideas with Merit intends to support innovative projects in the use of information and knowledge and supporting curricula. It allows disguising best practice and best using libraries. Under this application 108 projects have been supported so far (Fig.3). 


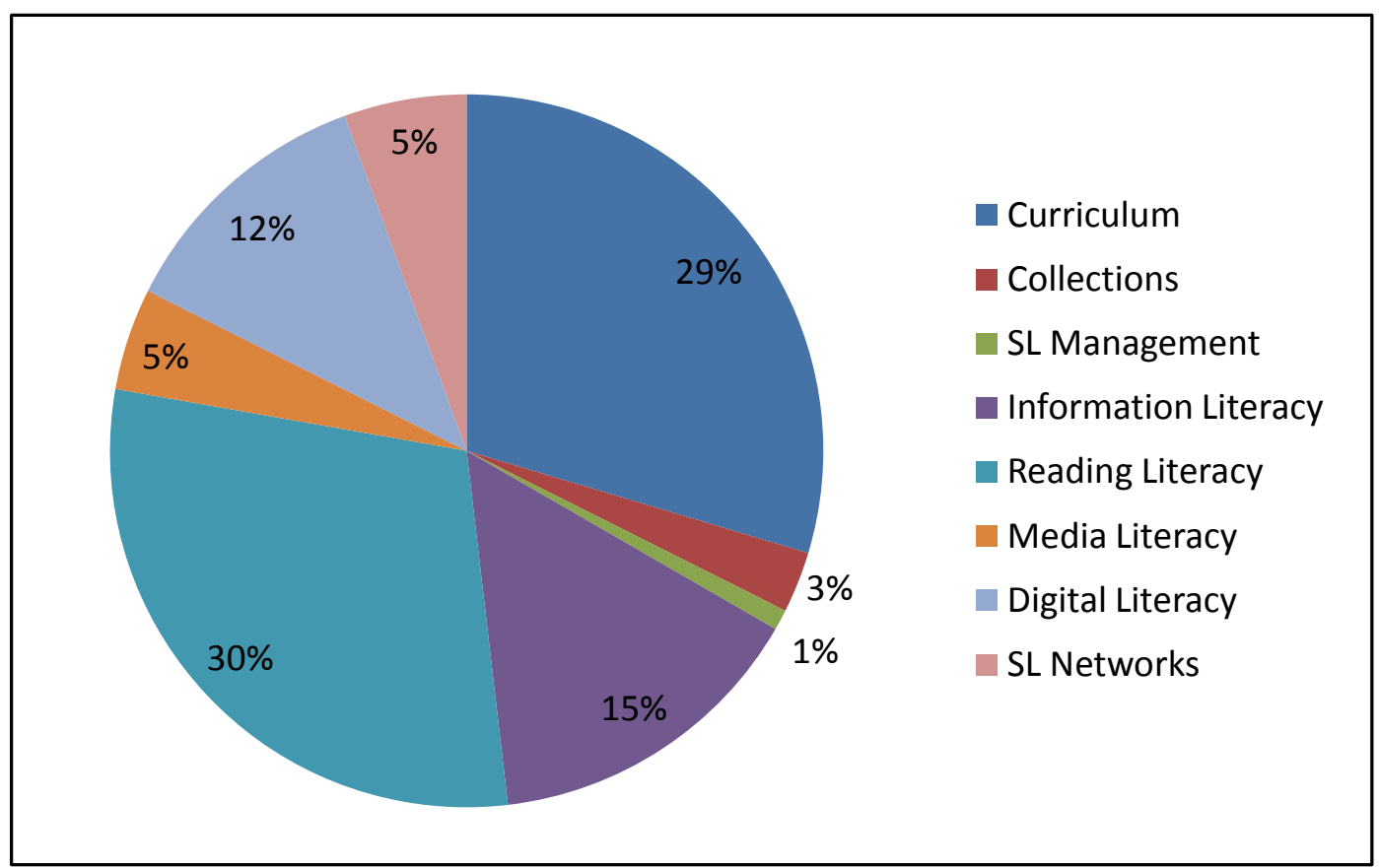

Fig. 3. Projects supported by the Ideas with Merit Application per area: 2005-2016

The future trend for the three types of candidacy points out, therefore, for a smaller weight of Network integration and greater convergence of requalification and of merit, betting heavily on libraries renovation based on building and implementing innovation projects.

\section{Technological innovation}

In a global world united by technology and marked by the growth, dispersion and variety of information, school libraries are no longer just physical spaces of access to the collections. Today libraries are called for new ways of managing information and knowledge, ensuring evaluation and validation of different sources and resources, promoting their organization and dissemination, stimulating physical and virtual access to documentation and information that support the curriculum and school activities. Digital libraries, Web OPACs, virtual reference services, online databases, Internet Portals, e-learning platforms, blogs, social networks and other curatorship web2.0 services, sharing and users interaction make up the libraries information and communicational landscape of nowadays.

School libraries must adapt to these new contexts and needs, investing in new infrastructures and technological equipments, providing new spaces and features, both for work and play, for reading, writing and audiovisual and multimedia production, offering new resources and services (cloud computing, maker spaces, media labs, ...), deepening cooperation and networking with other libraries (academic, specialized, ...) and promoting new types of initiatives and training solutions (PLE; Flipped Classroom, Mobile learning / 
$B Y O D, \ldots)$, requiring the adoption of innovative strategies to guide change and ensure their sustainability.

According to data collected by the SLNP between 2012 and 2015 the number of mobile devices (laptops, tablets, e-readers) increased exponentially in school libraries, as shown in the graph (Fig. 4). But there is still a long way to go. It will be necessary to reorganize and modernize school library spaces and features to make them more flexible, and create new areas for media production; to thin collections, making more room for the display of new acquisitions, subscription or open access to eBooks, reference services, digital signatures, apps, games, educational resources and so on; to provide all school libraries with wireless internet; purchase more mobile digital devices and install new types of equipments and tools (interactive whiteboards, touch tables, 3D printers,...).

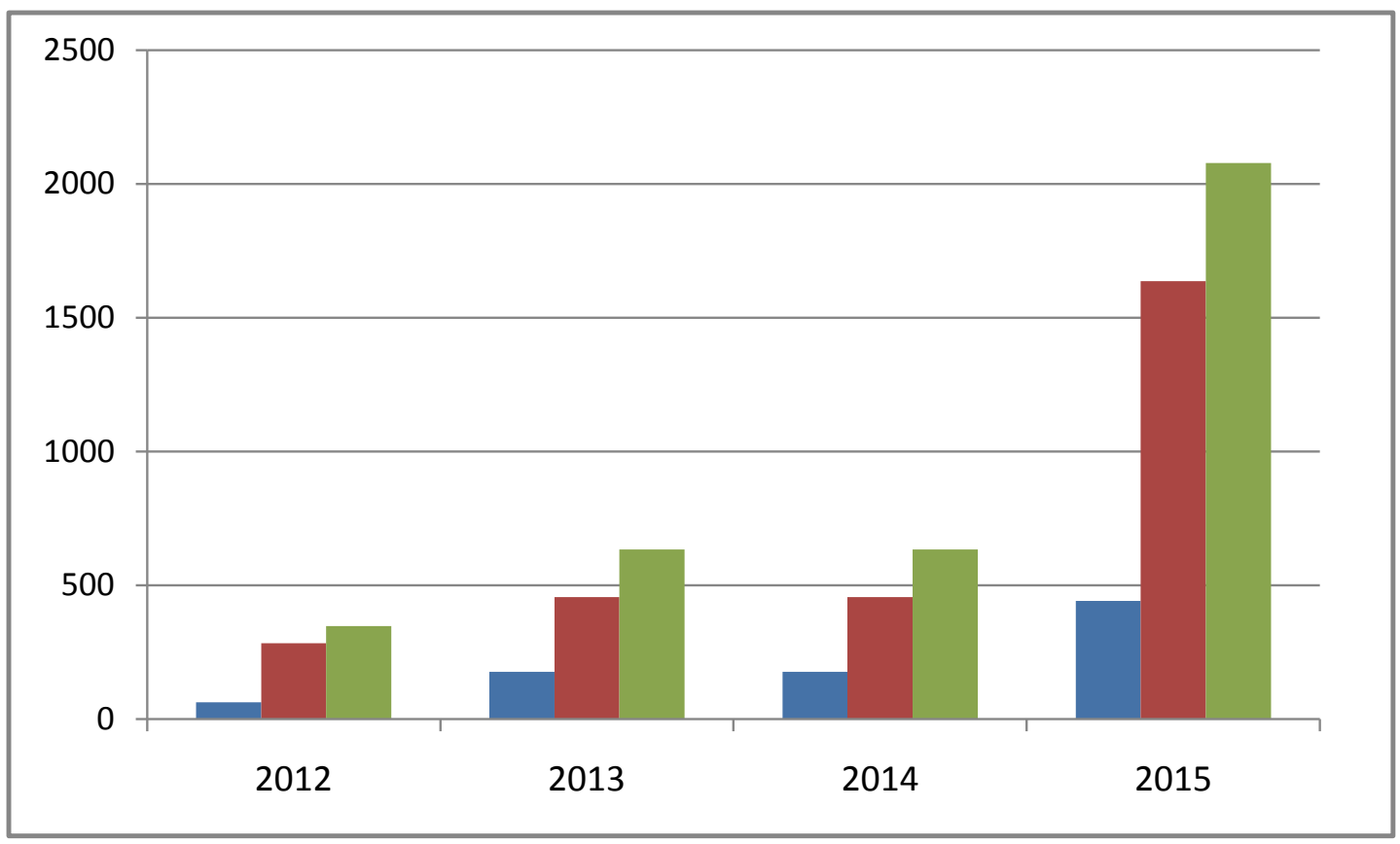

Fig. 4. Growth of Mobile Reading devices in school libraries: 2012-2015

It should be noted how important are the contacts with other organizations and the exploitation of economies of scale and shared purchases regarding, for example, the creation and management of digital libraries, the loan of eBooks, the availability of online services and platforms, etc. It is through partnerships with companies that some of these innovations have taken place. For example, through a partnership with a telecommunications company it was possible, in the context of the Project All together we can read to provide several libraries with specific equipment and digital resources for students with special educational needs. In another situation, it was possible to negotiate with publishers in 
favourable terms the signature of a learning platform and other resources to support the curricula. However this is not enough. We must definitely expand this type of inputs and consortia so that more libraries and students can benefit from pay or open digital solutions that favour updating teaching practices and learning.

\section{Cooperation and partnership projects with the Public Reading Network}

The intervention strategy of the SLNP has passed, as we have seen, by the establishment of projects and expanded partnerships that enhance the role of libraries opening them to communities and society, valorize the Program near other entities (universities, foundations, companies, broadcasting groups, etc.) and enable them to mobilize other resources that otherwise they would not have access to, contributing to their dynamism.

In this context, numerous cooperation projects have been created with different partners, public and private. They relate to global students education and citizenship building: reading, information, media, science, digital technologies, health, inclusion, heritage and others. Over 30 projects in these fields are currently being developed in partnership with the SLNP. The current strength and sustainability of the Program is due to a large extent to these kinds of projects.

Other important form of cooperation developed by SLNP is related to the municipalities. As the number of supported schools in each municipality kept growing and the links among school libraries and those with municipal libraries were reinforced, municipal networks of libraries, included in the same local network, began shaping up. They continue to play a strategic important role in the development of the Program.

This cooperation system with the municipalities - responsible for the supervision of schools from kindergarten and first cycle basic education - and their public libraries, where have been created support services to school libraries (SLSS), ensures a much broader response to schools, rationalizes resources, creates common services, share tasks, organizes joint activities, etc.

The creation of information systems providing computerization and networking of school libraries with each other and/ or with the municipal library was another essential aspect of this local cooperation, shown by the creation of nearly 50 portals and union catalogs and 700 school catalogs online (Fig 5). 


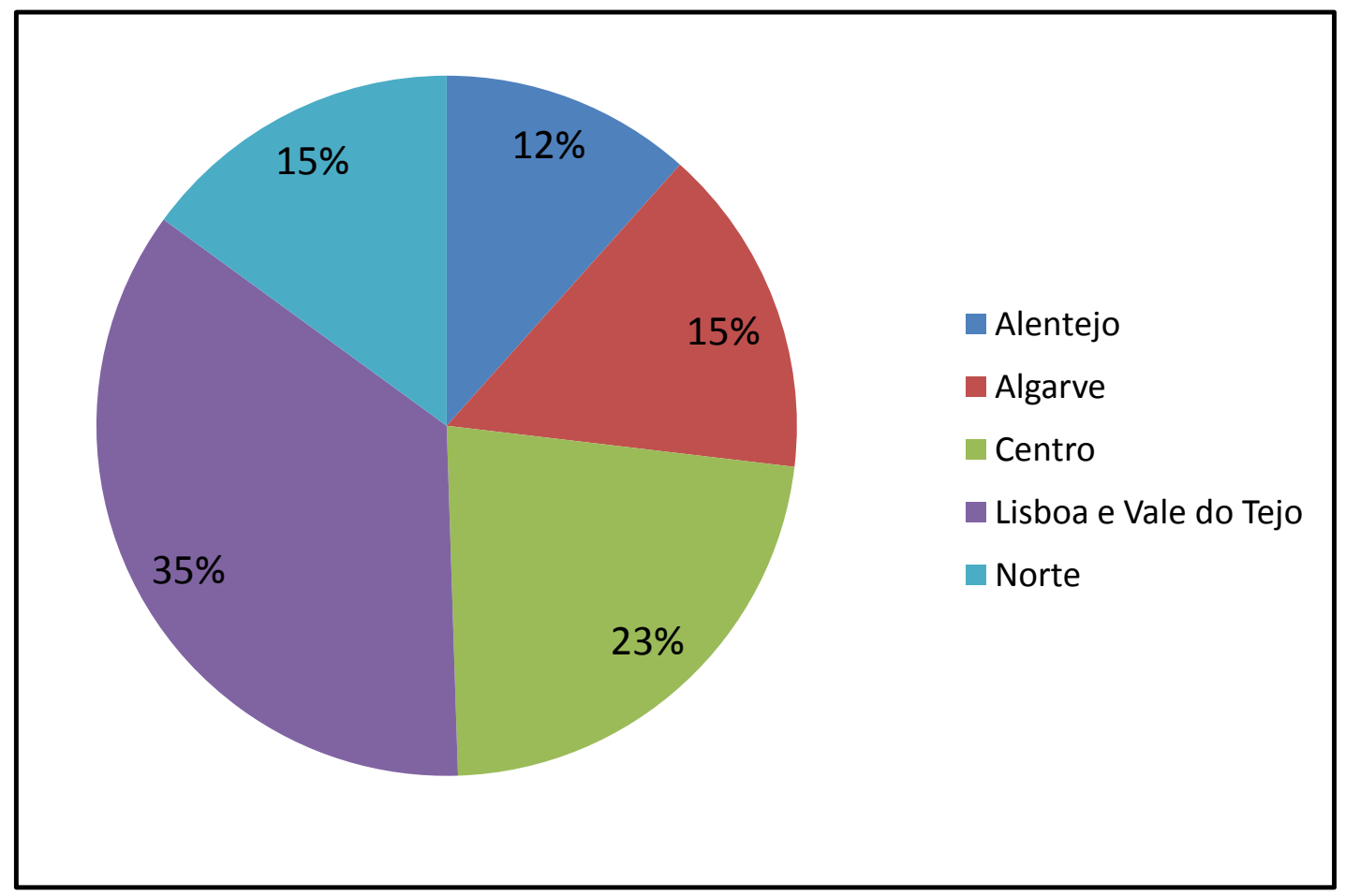

Fig.. 5. Bibliographic catalogs online

In a period of great connectivity and convergence, academic libraries, municipal, school libraries and other institutions (museums, archives, documentation centers, ...) benefiting from all the synergies that bind them together, should build partnerships, evolve to more advanced information and communication systems and take advantage of all the opportunities that the internet and multimedia offer today in products and services.

\section{Content production and tools to support school libraries}

The SLNP Coordinator Agency has been strongly committed in the creation of materials and information dissemination strategies and communication with schools, as the SLN Portal, social networks (Blog, Facebook and Twitter), the mailing list, the SLN Community in Sapo Campus, and others. Through these channels many documents and news have been shared, as illustrated by the item The Library presents itself, the dissemination of Good practices and the SLN Library publications.

The library presents itself is a set of videos produced by libraries in order to show their work and what they do best. Videos can cover many aspects, showing good examples and several space and functionality solutions, the organization of new services/resources or showing, educational and training activities of interest with an impact on students and the community. 
The dissemination of Good Practices in the SLN Portal has had an exemplary and replicator effect on schools. Since 2015, 30 best practices have been disseminated in this way, focusing on areas as diverse as the promotion of reading and literacy, communication and library marketing, the curriculum, the use of technologies, leisure activities, etc.

The SLN Library collection aims to promote the dissemination of studies and reflections that enhance the improvement of the quality of library services and its impact on school and learning.

In this context of information dissemination and supporting libraries work we must also to mention the utilization of resources and materials provided by the numerous projects and partnerships in which the SLNP participates (ex. Guides know the city; Newton liked to read; Platform Oral Health and School Libraries; Open Educational resources from The National Library and The National Archive Torre do Tombo, Databases and Training sessions of PORDATA and PORDATA Kids, and the National Institute of Statistics; House of Sciences, etc.).

Within the SLNP Action Plan, and related to the Learning with the School Library project, have also been published a set of lesson plans for the school library articulation with curricular activities. There is also intention to update other guidance documents to replace the existing ones in space organization and collection management.

At international level, the Program has developed strong efforts in building relationships, sharing experiences and dissemination its work. Thus, in addition to the presence of many guests in numerous regional meetings often held in Portugal, the great celebration of libraries in the IASL Conference of Lisbon in 2006 and the Grand Forum of libraries in 2013, under which numerous testimonies and promotional films were produced, the Program has been represented in IASL conferences, IFLA and other various initiatives undertaken in the context of the Ibero-American States (OEI) and the cooperation with the Portuguese-speaking countries, namely Mozambique and Timor. In 2016 the Program is celebrating its $20^{\text {th }}$ anniversary.

At operating level, and more particularly speaking of school libraries, it is also important to highlight the need to continue to improve their information services and users interaction through sites enrichment, the use of platforms and social networks (ex. Ask a librarian, notices /news, bibliographic information, digital bookshelves; provision of training contents, messenger services, reading groups, games, quizzes, etc.). 


\section{Habits and reading skills promotion}

The role of school libraries in forming competent readers and promoting reading habits is strongly consolidated. School libraries are now recognized as value structures, not only by offering multiple informative and literary works, increasingly available in different media and formats, but also and above all, through the design of systematic reading programs, understood as a basic and cross tool of knowledge and a cultural good for fun and pleasure. Clubs and social groups of reading, reading and writing workshops, digital books and book trailers publishing, reading passports, contests, Top readers and many other ideas are now part of the libraries day-to-day life.

The articulation with the National Reading Plan in many initiatives and projects, namely the National Reading Competition, the Reading Week and Reading+ projects, as well as the connection to other entities in education and culture, have been key assets for the success of this reading policy with tangible results in the improvement of PISA, PIRLS and other studies results.

In the latest PISA report (2012) Portuguese students have reached 488 points in Reading. Although having not yet reached the average value of 500 points, this progress was praised by reporters, who point out that Portugal is part of a group of countries that has shown more consistent and significant improvement. Increased reading comprehension through improved learning and reading practices have certainly contributed for these results.

The continuation of a strong focus on strategies for the development of reading levels, operated through new techniques, resources and tools able to motivate and empower young people to reading continues thus to be a priority of the SLNP.

\section{Curricular articulation and integration of literacies in learning}

More than organized resources centers, school libraries are assumed today as formative structures of learning and knowledge building, focused on new pedagogical approaches, based on research, information processing and communication and intensive use of new digital resources and media.

In the new digital era, school libraries are no longer simple information spaces. They stand increasingly as pedagogical structures, engaging with schools and communities and cooperating with teachers and students, in order to meet their educational needs and integrate into the curriculum the cognitive, instrumental and ethical skills that are in today's society a citizenship condition. 
That is why we can repeatedly witness in school libraries the collaborative work between classes and teachers in developing their activities and subject projects.

The implementation project of the Learning with the School Library framework, covering over 500 schools, is an example of this work.

Other examples are the organization of events and competitions and cross-cutting projects in digital literacy, information and media, per se or in partnership with other institutions, namely the Safety Internet Week; the competition Tell us a story! Podcast in Education; the contest 7 days 7 tips on the media; the Freedom of expression and social networks competition; the Reading is cool! contest; the Media Week; the involvement of libraries in school newspapers; school radios; joint activities with the Cinema National Plan and Citizenship Education, the participation in the Media Smart Program, etc. We therefore need to continue to pursue this dynamic and deepen the quality of work that is being carried out in schools in relation to all these initiatives, giving greater importance to the work of the library work in supporting the curriculum and integration of literacies in learning.

\section{School Libraries Staff and Training}

The privileged treatment of issues related to human resources allowed to obtain practical results of vital importance in the SLN development. The establishment of teacherlibrarians and the strong commitment in training were the most important. The challenges currently posed by the digital revolution and the knowledge society require from libraries an exceptional professional level of performance and efficiency. The answer to these challenges lies largely in the full-time teacher-librarian figure, institutionalized in 2009 and currently regulated by the law 192-A/2015.

Alongside this bet on human resources within the school library, were also designated an intermediate set of regional coordinators, responsible for monitoring and providing technical support to school libraries and to mediate between school libraries, the coordinator Agency and other partners. This kind of work is indispensable in the crucial phase of strong expansion and consolidation of the Program.

These regional coordinators are experienced and highly specialized, and have been responsible for most of the initiatives related to training, induction and projects and good practices development, organizing meetings and seminars and the consolidation of local networks in their territories.

The training of teacher-librarians, operational assistants in service in libraries, teachers in general and other school staff in areas related to libraries is being held under the general law on the training of teachers and not teaching staff, being promoted by different entities: School 
Associations Training Centers, Schools of Education, Universities, General Directorates, professional associations, etc.

This training has resulted in numerous highly attended training courses, in-person and online. They cover initial training, in-service and postgraduate, and aim at training and constantly updating professionals in management, reading, literacies, curricular articulation and digital technologies.

The success of this work depended on many factors due to SLNP by establishing an annual training plan with a set of training actions already approved; the management and maintenance of a continuous training actions data base and of postgraduate training courses; the establishment of benchmarks for training actions and their availability for training providers; and the availability of a platform for distance education for carried out elearning actions.

But the continued training of teacher librarians as media librarians continues to be fundamental. So, the present priorities are the training in ICT as a learning tool; digital educational resources production; the aggregation and curation of contents; and all literacies promoter in conjunction with the curriculum.

The creation of free modules, webinars and other training opportunities for self-training on different topics is also expected.

\section{Evaluation}

The enunciation of the key points of the SLNP does not replace the need for further reflection on the results to correct and improve strategies and procedures and meet the problems experienced by schools and all who are called to collaborate in this project.

The release in all school clusters and not grouped schools of the School Libraries Evaluation Model has been a very important factor for monitoring and improving their work, and for appreciation and recognition of their role.

The model is structured in four domains - related to the actions, results and libraries impacts in learning and curriculum coordination, in promoting pleasure for reading and reading and literacies skills and the statement of the social and cultural value of libraries.

The assessment is based on methods and varied techniques, quantitative and qualitative, that show the degree of efficiency and effectiveness of the services provided, the level of user satisfaction and the impact of activities in teaching and learning. 
In the first evaluation cycle (2010-2013), more than 20,000 teachers and about 100,000 students were surveyed and about 1300 teachers librarians produced thousands of reports. $75 \%$ of libraries showed positive or very positive ( 3 and 4 ) overall results over this period (Fig. $6)$.

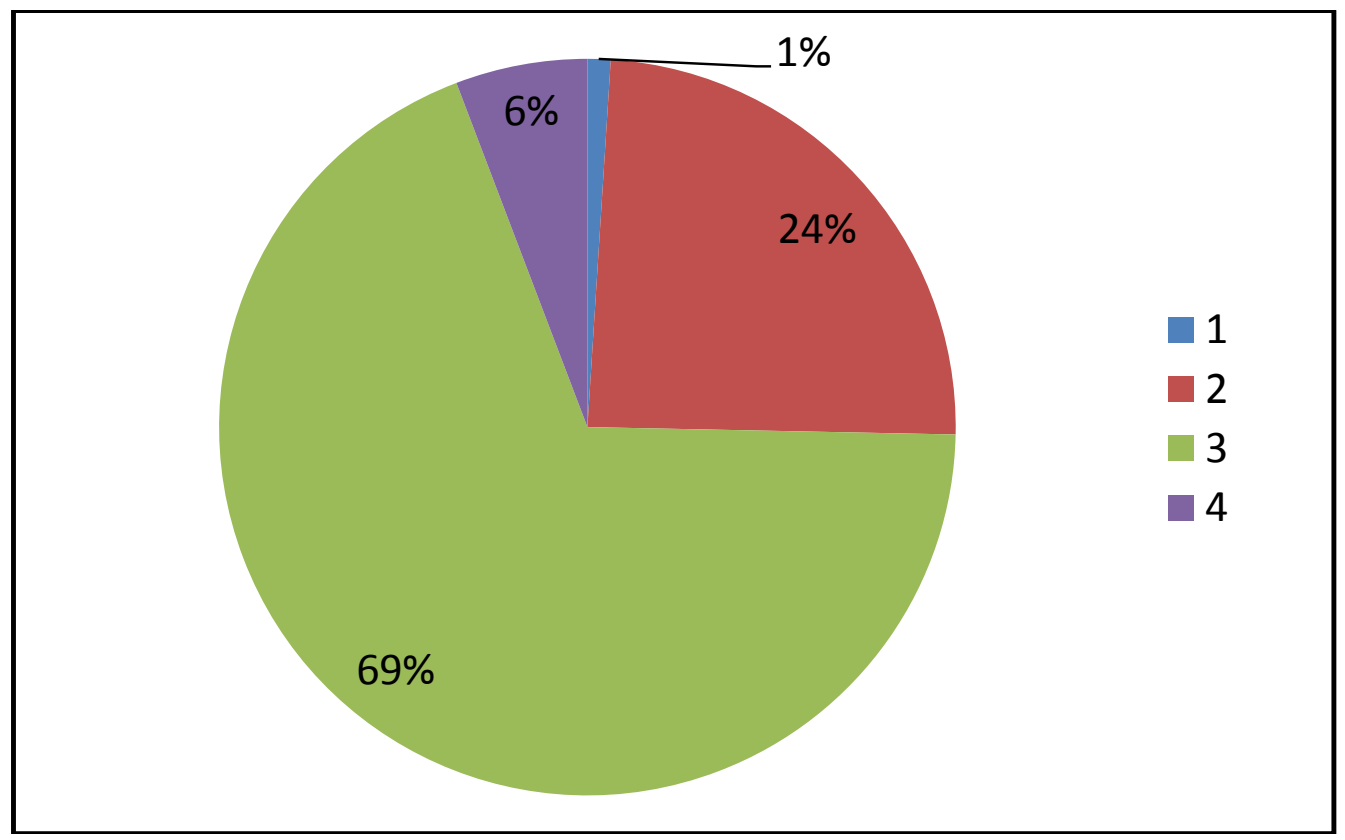

Fig. 6. Evaluation: levels obtained (2010-2013)

In this cycle (2014-2017), the application of the model switch from query and information analysis moments to reflection and design of improvement plans periods to address the weaknesses detected. The process started with the implementation in all school clusters/ non-grouped schools of more than 1,300 improvement plans based on the results of the previous evaluation. In 2015 schools answered the first set of questionnaires available through the computer application of SI RBE and it was presented the first monitoring process report.

Fig. 7 shows population questioned by schools, administered questionnaires and the reports submitted at the SLNP Information System over the period 2010-13 and in 2015, emphasizing the high mobilization of schools throughout the process and the significant growth in the number of actors and response rates in the new assessment cycle. 


\begin{tabular}{|c|c|c|c|c|c|}
\hline & \multicolumn{4}{|c|}{$2010-13$} & \multirow{2}{*}{$\begin{array}{c}2014-15 \\
2015 \\
\end{array}$} \\
\hline & 2010 & 2011 & 2012 & 2013 & \\
\hline Students & $\begin{array}{c}90705 \\
12,60 \%\end{array}$ & $\begin{array}{c}99390 \\
12,33 \%\end{array}$ & $\begin{array}{l}104812 \\
12,62 \%\end{array}$ & $\begin{array}{l}108080 \\
13,27 \%\end{array}$ & $\begin{array}{l}112871 \\
15,08 \%\end{array}$ \\
\hline Teachers & $\begin{array}{c}25132 \\
28,55 \% \\
\end{array}$ & $\begin{array}{c}22226 \\
27,36 \%\end{array}$ & $\begin{array}{c}19987 \\
27,46 \% \\
\end{array}$ & $\begin{array}{c}18660 \\
27,73 \%\end{array}$ & $\begin{array}{c}47322 \\
55,87 \%\end{array}$ \\
\hline Families & $\begin{array}{l}24012 \\
8,67 \% \\
\end{array}$ & $\begin{array}{l}28597 \\
9,89 \% \\
\end{array}$ & $\begin{array}{l}23094 \\
9,42 \% \\
\end{array}$ & $\begin{array}{l}16476 \\
7,95 \% \\
\end{array}$ & $\begin{array}{c}41786 \\
10,26 \% \\
\end{array}$ \\
\hline Principals & $\begin{array}{c}1525 \\
27,22 \% \\
\end{array}$ & $\begin{array}{c}1603 \\
22,67 \% \\
\end{array}$ & $\begin{array}{c}2276 \\
27,54 \% \\
\end{array}$ & $\begin{array}{c}1238 \\
25,02 \% \\
\end{array}$ & $\begin{array}{c}1167 \\
62,21 \% \\
\end{array}$ \\
\hline $\begin{array}{l}\text { Quests } \\
\text { sended }\end{array}$ & 80471 & 134944 & 140165 & 125827 & 119889 \\
\hline $\begin{array}{l}\text { Quests } \\
\text { received }\end{array}$ & $\begin{array}{c}34575 \\
42,96 \% \\
\end{array}$ & $\begin{array}{c}63594 \\
47,12 \% \\
\end{array}$ & $\begin{array}{c}53943 \\
38,48 \% \\
\end{array}$ & $\begin{array}{c}48306 \\
38,39 \% \\
\end{array}$ & $\begin{array}{c}75378 \\
62,87 \% \\
\end{array}$ \\
\hline $\begin{array}{l}\text { Reports } \\
\text { generated }\end{array}$ & 1137 & 1115 & 1612 & 1387 & 1371 \\
\hline
\end{tabular}

Fig. 7. SL Evaluation: Reporting population and reports generated by the SLNP Information System

Fig. 8 shows the results of 2015 concerning levels assigned by libraries in profiles of a number of areas. Regardless the changes in criteria in relation to the previous cycle, it is remarkable the very positive review achieved, with $44 \%$ of the libraries at level $4,43 \%$ at level 3 , and only $12 \%$ and $1 \%$ at levels 2 and 1 .

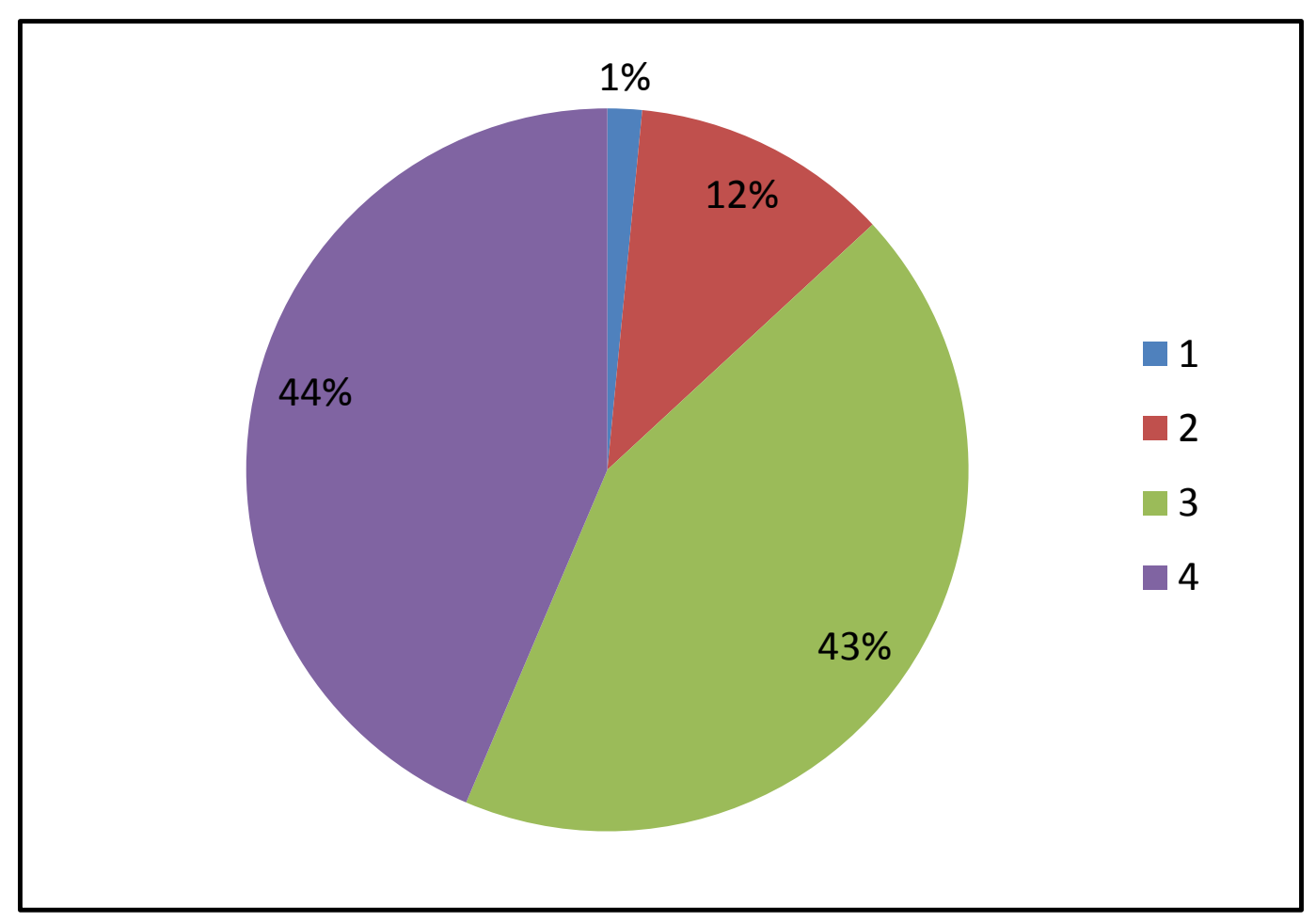


Fig 8. Evaluation: achieved levels (2015)

We can say that it is being paid particular attention, not only to the consolidation of good results but, above all, to overcome the weaknesses and the development of libraries, trying to achieve the top model standards benchmarks and meet the scenarios set out in the strategic framework of the Program.

In 2009 the SLNP was also the subject of an external evaluation by an independent institution of higher education. This initiative should hopefully be repeated in a near future.

\section{Conclusion}

We can say that school libraries are today considered as a basic resource for schools, the educational community joining these spaces which they recognize as fundamental parts of the general strategy for change in Education and of the adoption of new ways of teaching and learning.

So far, the experience let us think there are good perspectives for the future development of school libraries. It will depend, first of all, on the way public authorities, schools and communities are able to continue to evolve and take ownership of this innovation project.

There are still many and fundamental tasks to accomplish so that libraries and schools may occupy their rightful place in the new society. The development of SL relies today on a set of interdependent actions that only the cooperation of schools and many different institutions, programs and initiatives can provide.

The SLNP will pursue its goals in contributing to this development, always cooperating with all organizations pursuing the same end.

As it is written in the last leaflet published by the SLNP, we bet on:

\footnotetext{
$>$ quality of the network

$>$ quality of educative service with impact in students success

$>$ adaptation to technological and digital issues

$>$ raising of literacy levels

$>$ innovative knowledge and citizenship spaces
}

Libraries are a basic resource of the educational process and should as such constitute a privileged space and place of the school. The society that invests in the school library invests in its own future. 


\section{References}

Calçada, T. \& Martins, A. B. (2014). A Rede de Bibliotecas Escolares. In: 40 Anos de Políticas de Educação em Portugal, vol. II: Conhecimento, atores e recursos. Org. Maria de Lurdes Rodrigues. Coimbra, Almedina.

Lançar a Rede de Bibliotecas Escolares: relatório síntese (1996). Coord. Isabel Veiga. Lisboa: Ministério da Educação. Accessed at: http://www.rbe.mec.pt/np4/file/446/972 729018 3.pdf OECD (2014). PISA 2012 results in focus: What 15-year-olds know and what they can do with what they know: Key results from PISA 2012. Accessed at: http://www.oecd.org/pisa/keyfindings/pisa-2012-results-overview.pdf Rede de Bibliotecas Escolares (n.d.). Bibliotecas. Accessed at: http://www.rbe.mec.pt/np4/mapas/ Rede de Bibliotecas Escolares (n.d.). Boas Práticas. Accessed at: http://www.rbe.mec.pt/np4/boas praticas/ Rede de Bibliotecas Escolares (n.d.). A biblioteca apresenta-se. Accessed at: http://www.rbe.mec.pt/np4/820.html Rede de Bibliotecas Escolares (n.d.). Biblioteca RBE. Accessed at: http://www.rbe.mec.pt/np4/conteudos/?tag=biblioteca+rbe Rede de Bibliotecas Escolares (n.d.). Projetos e Parcerias. Accessed at: http://www.rbe.mec.pt/np4/projetos parcerias/ Rede de Bibliotecas Escolares (2010). Avaliação do Programa Rede de Bibliotecas Escolares. Coord. António Firmino da Costa ...[et.al.]. Lisboa: RBE. Accessed at: http://www.rbe.mec.pt/np4/file/31/978 $972 \quad 742 \quad 3194 . p d f$ Rede de Bibliotecas Escolares (2011). Modelo de avaliação da biblioteca escolar: [20102013]. Coord. Elsa Conde, Rosa Martins e Glória Bastos. Lisboa: RBE. Accessed at: http://www.rbe.mec.pt/np4/file/83/mabe.pdf Rede de Bibliotecas Escolares. (2012). Aprender com a biblioteca escolar: referencial de aprendizagens associadas ao trabalho das bibliotecas escolares na educação pré-escolar e no ensino básico. Coord. Elsa Conde... [et.al.]. Lisboa: RBE. Accessed at:

http://www.rbe.mec.pt/np4/conteudos/np4/?news/d=681\&fileName=Aprender com a bibliot eca escolar.pdf

Rede de Bibliotecas Escolares. (2013a).Modelo de avaliação da biblioteca escolar: 20142017. Coord. Elsa Conde, Rosa Martins e Paula Ochôa. Lisboa: RBE. Accessed at: http://www.rbe.mec.pt/np4/file/1047/978 972742365 1.pdf Rede de Bibliotecas Escolares. (2013b). Programa Rede de Bibliotecas Escolares. Quadro estratégico: 2014-2020. Lisboa: RBE. Accessed at: http://www.rbe.mec.pt/np4/np4/?newsld=1048\&fileName=978 972742366 8.pdf 


\section{Biographical Note}

Elsa Conde has an advanced degree in Library Science and a master's degree in Educational Multimedia Communication.

Between 1980 and 1995 she was a teacher in basic and secondary schools.

In 1997 she joined the staff of the School Library Network Program, where she works as school librarian adviser and municipal coordinator.

She is coauthor of several documents published by the SLNP.

She is responsible for monitoring of the SLNP cooperation project in Mozambique.

Since the ' 90 she has also been a trainer in the area of libraries and participated in various national meetings and conferences. Her main professional topics are reading, media and information literacy. 